\title{
CHAPTER 19 \\ PROCESS-ORIENTED MANAGEMENT OF ENTERPRISES: THE ESSENCE, CONTENT AND FEATURES OF APPLICATION
}

\section{Cherchata A. O.}

\section{INTRODUCTION}

Traditional management methods in current economic environment no longer provide the ability to make strategically correct decisions. In order to create lasting advantages over competitors, a modern enterprise needs to have an effective system of managing its activities, which can be implemented under certain methodological and organizational approaches. In current difficult economic environment, purposeful management of the enterprise should be realized on the critical selection of the best achievements of scientific schools and approaches to management. In the context of globalization and European integration, modern management concepts are oriented towards a process-oriented approach to the formation of a management system. This means that the main management object is the process. The experience of implementing business process management (BPM) concepts by leading world enterprises gives grounds to assert the emergence of a progressive theory of enterprise management, which has an ability to achieve the desired result even in the conditions of radical changes in the internal and/or external environment. Business processes are the essence of BPM methodology. On their basis financial efficiency of activity is determined, business culture is formed and transition to a qualitatively new organizational structure is made.

Process management differs from the functional one first of all in the way of business process' formation as a sequence of actions aimed at achieving measurable end result. In this case, the emphasis is shifted from the management of individual resources and the cost centers to the management of business processes, which together link the activities of all interacting units of the enterprise. This increases not only the level of coordination of production and economic operations, but also the level of productivity and quality of work. It concentrates management on obtaining the end result of the business process. Thus, the improvement 
of the performance of the enterprise is determined by the efficiency of business process management. The use of process approach is the basic principle of formation of quality management system and total quality management (TQM), implementation of concepts such as business process reengineering, continuous improvement of business processes, Balanced Scorecard (BSC).

\subsection{Analytical characterization of development tendencies of management approaches and substantiation of expediency of process oriented management implementation at enterprises}

In the second half of the XX century, such approaches to management as system, structural, functional, process were developed and became widespread.

Scientists ${ }^{12}$, define the system approach as a methodology for researching and managing objects as systems. Thus, an organization is seen as a system of interrelated elements (people, structure, tasks, technologies) focused on achieving a specific goal in a changing environment. The main task is to establish a predetermined state of operation of the system provided by the planning. However, it is difficult to implement a systematic approach because large-scale systems are complex enough. It is difficult to track the interaction of multiple subsystems within an enterprise and set system boundaries, which can lead to the accumulation of unnecessary and inappropriate data or partial resolution of problems.

The structural approach is focused on determining the importance, priorities, methods, principles and other tools in their union in order to establish rationality of the validity of resource allocation increasement ${ }^{3}$. This approach is based on the use of different types of organizational structure of the enterprise, usually hierarchical. In this case, the organization and management of activities is carried out by structural elements (departments), and their interaction - through officials (heads of departments) and higher-level structural units. There are several disadvantages of the structural approach:

\footnotetext{
1 Ansoff I. (1989) Strategicheskoye upravleniye [Strategic Management]. Moscow: Economic. (in Russian)

${ }^{2}$ Redchenko K. I. (2003) Stratehichnyi analiz u biznesi [Strategic analysis of business]. Lviv: The New World - 2000. (in Ukrainian)

${ }^{3}$ Gershun A. (2006) Tekhnologii sbalansirovannogo upravleniya [Technologies of the balanced management]. Moscow: Olimp-Biznes. (in Russian)
} 
- splitting technologies of workflow into separate fragments can assign them to different elements of organizational structure;

- it is difficult to fully describe the technologies of workflow, basically there is only a fragmentary (at the level of structural elements) description;

- lack of responsibility for the end result, orientation towards the end consumer;

- significant time spent for transferring results between units.

The functional approach is based on the decomposition of the production process into tasks in order to further improvement ${ }^{4}$. Alternative options are those that require minimum total cost. With a functionally oriented approach, a number of functions are assigned to each structural unit and responsibility is described, the performance criteria are formulated. Horizontal linkage between structural units is weak. The vertical structure «chief - subordinate» is quite strong. Functional-structural model is based on the universal principle of division of labor between units, with the fixation of certain functions (operations). The main disadvantage of this structure is that the functions are assigned to the units often by different methods, and in the course of the enterprise activity there is an increase of these functions. In addition, this structure has significant costs for the maintenance of the administrative apparatus. In view of the above, a number of scientists ${ }^{56}$, believe that in the present conditions there are objective prerequisites for reorientation from functional to process management.

According to ${ }^{7}$, the process approach adequately reflects the production structure of the enterprise as a structure of business processes. It contains a systemic vision of the management object, its structural construction, functional orientation of barriers that impede the optimal promotion of business processes. Mescon M.H. ${ }^{8}$ stated that process approach refers to «an approach to management theory based on the concept that management is a continuous series of interrelated actions or functions.» In this approach, the enterprise management

\footnotetext{
${ }^{4}$ Tompson A., Stryklend A.Dzh. (2005) Strategycheskyj menedzhment: koncepcyy y sytuacyy dlja analyza [Strategic Management: Concepts and situations for analysis]. Moscow: Williams. (in Russian)

Albrekht N. A. (2007). Sistema korporativnykh standartov: praktika razrabotki i vnedreniya. Reglamentatsiya biznes-protsessov [The system of corporate standards: the practice of development and implementation. Regulation of business processes]. Management Accounting and Finance, no. 2, pp. $144-152$.

${ }^{6}$ Jeston J., Nelis J. (2006) Business Process Management: Practical Guidelines to Successful Implementations. Amsterdam: Elsever.

${ }^{7}$ Ibid.

${ }^{8}$ Meskon M., Albert M., Hedouri F. (2005) Osnovy menedzhmenta [Fundamentals of Management]. Moscow: Delo, p. 48. (in Russian)
} 
system is focused on managing both each business process individually and all business processes as a system. The essence of the process approach is that each employee ensures the functioning of specific business processes. Responsibilities, areas of responsibility, success criteria for each employee are formulated and only make sense in the context of a specific task or process. The horizontal connection between structural units is much stronger. Unconditional priority of the vertical communication «chief - subordinate» weakens because of importance of horizontal cooperation between divisions of the enterprise.

The concept of a process approach originated within a classical school that described management functions but as independent of one another. A. Fayol identified five output management functions; in his opinion, «to manage means to foresee and plan, organize, dispose, coordinate and control» ${ }^{9}$.

Contrary to these views, the later development of a process approach leads experts to consider management functions as interrelated. Modern principles of process management are based on the modeling of business processes, which describe how different management functions are performed and interact with each other. According to M. Mescon, the management process consists of four interrelated functions: planning, organization, motivation and $\operatorname{control}^{10}$. Authors ${ }^{11}$ define process approach as orientation of activity on business processes. Therefore, systems of enterprise management should focus on each business process individually and also consider them as a system at the enterprise level within the framework of certain projects.

However, a number of scientists, in particular ${ }^{12}{ }^{13}$, state that the process approach is not the opposition to functional one.

For this purpose, there is a need to analyze the concepts of «process» and «function».

\footnotetext{
${ }^{9}$ Fayolle A., Emerson G., Taylor F., Ford G. (2002) Menedzhment - eto iskusstvo [Management - is art]. Moscow: Unity, p. 12. (in Russian)

${ }^{10}$ Meskon M., Albert M., Hedouri F. (2005) Osnovy menedzhmenta [Fundamentals of Management]. Moscow: Delo. (in Russian)

${ }^{11}$ Repin V. V., Yeliferov V. G. (2008) Protsessnyy podkhod k upravleniyu. Modelirovaniye biznesprotsessov [Process approach to management. Business process modeling]. 6th ed. Moscow: Standards and quality. (in Russian)

${ }_{12}$ Albrekht N. A. (2007). Sistema korporativnykh standartov: praktika razrabotki i vnedreniya. Reglamentatsiya biznes-protsessov [The system of corporate standards: the practice of development and implementation. Regulation of business processes]. Management Accounting and Finance, no. 2, pp. $144-152$.

${ }_{13}$ Jeston J., Nelis J. (2006) Business Process Management: Practical Guidelines to Successful Implementations. Amsterdam: Elsever.
} 
In the great encyclopedic dictionary a function is defined as: activity, work, the external display of the properties of any object in a given system of relations, as the role played by a particular social institution or process in relation to the whole ${ }^{14}$. From the point of view of management, classical management theory defines the function in terms of organizational structure of management and treats it as a series of interrelated actions, united by features to achieve the goals of the enterprise $^{15}$.

In the modern economic dictionary, the process is defined as a sequential change in the states in the development of something, a set of sequential actions to achieve any result ${ }^{16}$. The founders of a process approach define a process (business process) as a set of different activities within which one or more types of resources are used at the «input», and as a result of this activity at the «output» the value to the consumer is created ${ }^{17}$.

Based on the results of the analysis of these definitions, it should be noted that the main difference between a business process and a function is that the process includes a time category, changing the state of the object in its motion to the final state. At the same time, with the help of functional approach the answer to the next questions can be stated: who does and what does. With the help of process approach the next questions can be answered - who, what, how, in what sequence and with what result.

Despite all the advantages of the process approach, it should be emphasized that functional specialization provides the least costs for individual operations within the business process. In view of the above, it is believed that functions and processes are equivalent to management concepts and cannot exist separately.

The result of both functional and process approaches is the simultaneous design of the organizational structure (functional areas) and the order of interaction within that structure (processes). These approaches should be applied simultaneously. The main difference between the process and functional approach is that the first is primarily

\footnotetext{
${ }^{14}$ Azriljan A. (ed.) (2010) Bol'shoj jenciklopedicheskij slovar' [The Great Encyclopedic Dictionary]. Moscow: Knizhnyj mir. (in Russian)

${ }^{15}$ Meskon M., Albert M., Hedouri F. (2005) Osnovy menedzhmenta [Fundamentals of Management]. Moscow: Delo. (in Russian)

${ }^{16}$ Rajzberg B. A., Lozovskij L. Sh., Starodubceva E. B. (1999) Sovremennyj jekonomicheskij slovar' [Modern Economic Dictionary]. Moscow: INFRA-M. (in Russian)

17 Andersen B. (2003) Biznes-protsessy. Instrumenty sovershenstvovaniya [Business processes. Improvement tools]. Moscow: Standards and Quality. (in Russian)
} 
focused not on the organizational structure of the enterprise or the functions of units, but on business processes whose ultimate goal is to create goods or services that are of value to external or internal consumers. In this case, the enterprise management system is oriented both at managing each business process individually, and all business processes as a system.

Recently, the process approach has become increasingly important due to the development of information technology and the need for enterprise restructuring. The methodology of enterprise restructuring, according to ${ }^{18}$, is intended to solve the following tasks: to provide strategic planning of activities; to implement a process approach to enterprise management, which will allow to concentrate resources on restructuring and to use them more effectively in further operation of key business processes; implement knowledge management at all stages of restructuring.

A number of scientists ${ }^{19},{ }^{20},{ }^{21}, 22,{ }^{23}$ determine the main reasons for the implementation of the process approach in the enterprise. Firstly, in today's uncertainty, national businesses need to respond quickly and efficiently to all kinds of changes, in a timely manner, and sometimes with anticipation, to make changes to management decisions in the changing circumstances, possibly through changes in regulations of business processes. Secondly, the attitude of consumers and stakeholders to the quality category has recently changed: if the quality of the finished product was the priority, now it is the quality of all processes, from development and production to end-of-life processes. Thirdly, the representation of the production structure of the enterprise through the interconnection of business processes more accurately reflects the real structure of the enterprise. Moreover, the organizational structure is reorganized with respect to business processes. That is done by

\footnotetext{
18 Totskiy V.I., Lavrenenko B. I. (2005) Orghanizacijnyj rozvytok pidpryjemstva [Organizational development Enterprise]. Kiev: KNEU. (in Ukrainian)

19 Abdelkafi N., Täuscher K. (2016) Business models for sustainability from a system dynamics perspective. Organization and Environment, vol. 29, no. 1, pp. 74-96.

${ }^{20}$ Antunes P., Mourão H. (2011) Resilient business process management: Framework and services. Expert Systems with Applications, vol. 38, no. 2, pp. 1241-1254.

${ }^{21}$ Cherchata A. (2016) Formuvannja pokaznykiv rezuljtatyvnosti ta efektyvnosti biznes-procesiv na osnovi koncepciji Balanced Scorecard (BSC) [Formation of Indicators of Resultativity and Effectiveness of Business Processes on the Basis of the Balanced Scorecard (BSC) Concept]. Scientific Bulletin of Ivano-Frankivsk National Technical University of Oil and Gas, vol. 14, no. 2, pp. 137-143.

${ }^{22}$ Cherchata A., Popovychenko I., Andrusiv U., Simkiv L., Kliukha O., Horai, O. (2020) A methodology for analysis and assessment of business processes of Ukrainian enterprises. Management Science Letters, vol. 3, no. 10, pp. 631-640.

${ }^{23}$ Kratzer S., Lohmann P., Roeglinger M., Rupprecht L., zur Muehlen M. (2019) The role of the chief process officer in organizations. Business Process Management Journal, vol. 4, no. 25, pp. 688-706.
} 
eliminating those functional units that do not fall into the group of ancillary processes and do not have a significant impact on the value chain to meet consumer demands. And, fourth, the enterprise simultaneously operates a large number of processes that implement the functions of the enterprise.

When analyzing the scientific works related to enterprise management based on the process approach, it has been noted that much attention is paid to the approaches and problems of implementation of the process approach, on which the effective functioning of the enterprise depends ${ }^{24}, 25,26$. The results of the study allowed to distinguish the main stages of process approach implementation:

- definition and identification of business processes and the order of their interaction in the overall network of business processes of the enterprise;

- a clear division of responsibilities and powers for each business process of the enterprise;

- defining criteria and methods for evaluating the effectiveness and efficiency of business processes;

- development and approval of regulations that formalize business processes;

- managing resources and regulations in case of deviations in products, business processes or changes in the external environment.

Thus, the process approach not only describes the business as a network of interconnected processes, but also its continuous monitoring, management and improvement of business processes.

\subsection{The process of improving business processes through reengineering}

In order to ensure effective process management, considerable attention is paid to business processes optimization which support the activity of enterprises and are carried out with the aim of timely delivery of material, financial, information resources at the begining of business

\footnotetext{
${ }^{24}$ Trkman P., Mertens W., Viaene S., Gemmel P. (2015) From business process management to customer process management. Business Process Management Journal, vol. 2, no. 21, pp. 250-266.

${ }^{25}$ Lederer M., Kurz M., Lazarov P. (2017) Making strategy work: A comprehensive analysis of methods for aligning strategy and business processes. International Journal of Business Performance Management, vol. 18, no. 3, pp. 274-292.

${ }_{26}$ Becker J., Kugeler M., Rosemann M. (2010) Process management. Berlin, Germany: Springer.

27 Andersen B. (2003) Biznes-protsessy. Instrumenty sovershenstvovaniya [Business processes. Improvement tools]. Moscow: Standards and Quality. (in Russian)
} 
processes and timely delivery of the newly created value of a product or service to the end consumer at the final stage $\mathrm{e}^{28}$.

The majority of scientists consider reengineering as the main tool of improvement of business processes in modern conditions. It is defined as a fundamental rethinking and radical redesign of business processes in order to achieve significant changes in the main indicators of enterprise activity $^{29},{ }^{30}$. One of the main features of business process reengineering (BPR) is the orientation of this tool not on function but on process. At the theoretical level, it should be noted that there is a great variety of interpretation of the concept of business process reengineering, but the only point of view for this process has not been determined. Business process reengineering is a new approach to the formation of a management system and organizational structure based on the transition from functional units to teams of specialists responsible for a particular business process ${ }^{31}$. The management of material resources on the basis of BPR means strengthening the process approach to its organization, shifting the focus from functional to process management. The concept of «business process» is introduced as a set of sequential actions aimed at achieving a specific result, coordinated with the results of other business processes.

The analysis of theoretical achievements of scientists who investigated the problems of reengineering theory ${ }^{32},{ }^{33}$ has shown that this is a continuous process. It is important to clarify that this is not about redesigning different business processes, but about the continuous improvement of this business process, which was subjected to this change. Summarizing the above definitions, characterizing and integrating the views of the scientists ${ }^{34}, 35$, it can be concluded that reengineering is a tool for identifying the «bottlenecks» of the studied business processes and improving them through coordinated integration

\footnotetext{
${ }^{28}$ Mizyuk B. M. (2006) Stratehichne upravlinnya [Strategic management]. Lviv: Magnolia plus. (in Ukrainian)

${ }^{29}$ Davenport T. (1993) Process innovation: reengineering work through information technology. Boston: Harvard Business School Press.

30 Johansson H., McHugh P., Pendlebury J. (1993) Business process reengineering. Break-point strategies for market dominance / H. Johansson. N.Y.: John Wiley \& sons.

31 Manganelii R. L., Klein M. M. (1994) The reengineering handbook: a step-by-step guide to business transformation. N.Y.: Amacom.

${ }^{32}$ Davenport T. (1993) Process innovation: reengineering work through information technology. Boston: Harvard Business School Press.

33 Johansson H., McHugh P., Pendlebury J. (1993) Business process reengineering. Break-point strategies for market dominance / H. Johansson. N.Y.: John Wiley \& sons.

${ }^{34}$ Manganelii R. L., Klein M. M. (1994) The reengineering handbook: a step-by-step guide to business transformation. N.Y.: Amacom.

35 Vinogradova O. V. (2006) Reinzhyniryng torgivel'nyh pidpryjemstv: teorija ta metodologija [Reengineering of trading enterprises: theory and methodology] (Doctoral thesis), Donetsk.
} 
of the studied business processes in order to optimize the organizational structure of the enterprise. The degree of the level of improvement of business processes depends on their initial state and the industry in which the enterprise operates.

The stages of business process reengineering at the enterprise are shown in Figure 1.

Thus, the selection of business processes that require reengineering is carried out in the following sequence:

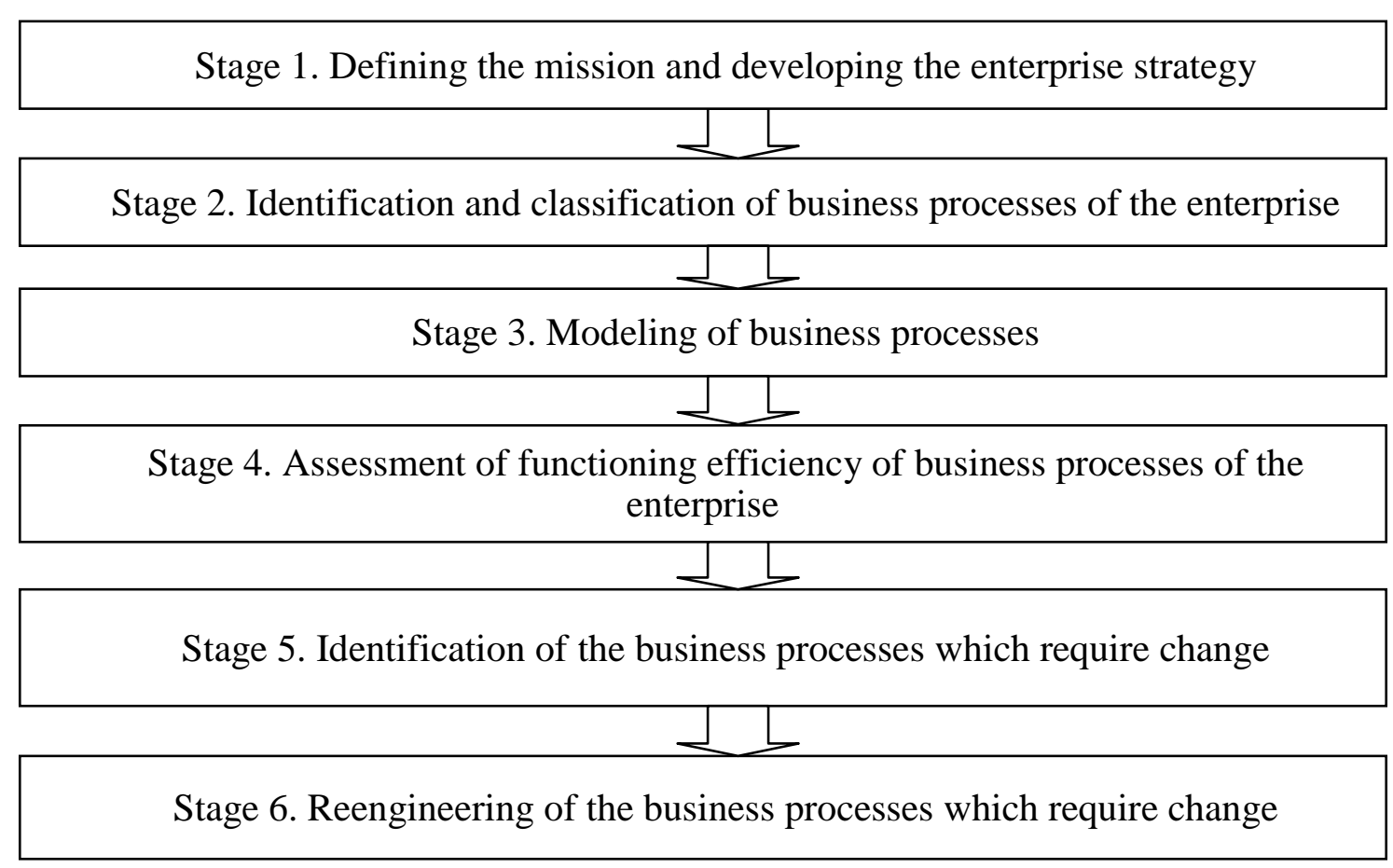

\section{Figure 1. Stages of reengineering of business processes of the enterprise}

Source: created by the author

1. Defining the mission and developing the enterprise strategy is an important stage. Changes that take place in the enterprise must be consistent with its mission, which is defined as provision of quality products or services. Taking into account the mission of the enterprise, its strategy is developed.

2. Identification and classification of business processes of the enterprise. It identifies business processes that are related to a particular business activity. 
3. Modeling of business processes allows to describe graphically business processes with the definition of tasks, responsibilities, inputs and outputs of certain business processes.

4. Assessment of functioning efficiency of business processes of the enterprise, allows to identify problematic business processes and those that are performed effectively.

5. Identification of the business processes which require change, that means ineffective processes.

6. Reengineering of the business processes which require change.

Enterprise management reveals the influence of external and internal events on the parameters of business processes. Such type of management requires purposeful regulation of these parameters to achieve the set goals. Accordingly, the performance of the enterprise is the evaluation criteria for the effect of managerial influence on business processes.

Correct identification and rational organization of business processes, timely research and assessment of the impact of business processes on the results of enterprise activities allow to identify problem areas and make effective management decisions.

It is suggested to use indicators that characterize the status of existing business processes as quantitative measures of the analyzed factors.

It should be noted that the enterprise is a complex economic object, which is described not by one criterion, but by a set of criteria characterized by different properties. It is important to note that in order to ensure the objectivity and reliability of the business process evaluation, it is necessary to use several interrelated criteria that would characterize different aspects of the activity.

In analyzing and evaluating the business processes of an enterprise, it is necessary to evaluate the effectiveness and efficiency of their implementation, since efficiency determine the various aspects of the functioning of business processes.

Effectiveness is determined by ISO 9000:2008 standards as a measure of achieving the intended results ${ }^{36},{ }^{37}$. Thus, the effectiveness of the business process shows the degree of compliance with the actual

\footnotetext{
36 ISO 9001-2008 Quality management systems. Fundamentals and vocabulary [електронний pecypc]. Retrieved from: http://www.iso.org

ISO 9004-2008 Quality management systems. Guidelines for performance improvements [електронний ресурc]. Retrieved from: http://www.iso.org
} 
results obtained to the stated goals, it means the degree of achievement of the expected state of the management object.

In accordance with the above standard, effectiveness is the ratio between the results achieved and the resources used. This is practically in line with the modern definition: «efficiency is the relative effect of a process, defined as the ratio of the effect (result) to the costs that led to (ensure) its receiving» ${ }^{38}$.

When identifying the criteria for evaluating the effectiveness of business processes, it is advisable to start with their goals and objectives, which are developed taking into account not only the strategic goals of the company, but also the specifics of business processes and consumer requirements for its results.

In order to substantiate the criteria and indicators for evaluating the effectiveness of the business processes of the enterprise, it is necessary to develop the stages of formation of these criteria (Figure 2).

1. Defining the strategic goals of the enterprise and the requirements of consumers and customers

2. Determination of the composition of business processes of the enterprise and their classification

3. Identification of business processes of the enterprise that can be improved through reengineering

4. Identification of business processes' objectives selected in Stage 3 that can be improved through reengineering

5. Determining the criteria for estimation of the effectiveness of the enterprise's business processes

6. Formation of indicators of effectiveness of business processes in the framework of the suggested criteria

\section{Figure 2. Stages of formation of criteria and indicators of estimation of effectiveness of enterprise's business processes}

Source: created by the author

The first stage. Determination of strategic goals of the enterprise and requirements of consumers. This stage is the development of longterm plans based on the maximum use of scientific, technical, industrial

\footnotetext{
${ }^{38}$ Azriljan A. (ed.) (2010) Bol'shoj jenciklopedicheskij slovar' [The Great Encyclopedic Dictionary]. Moscow: Knizhnyj mir. (in Russian)
} 
and human resources. The implementation of strategic plans depends on the level of development and management of business processes.

The second stage. Determining the composition of business processes, their classification and interaction. Enterprises carry out on average from 6 to 40 different business processes. Their classification contributes to their orderliness and helps to ensure the quality.

The third stage. Identification of enterprise business processes that can be improved through reengineering. At this stage, the coherence of business processes is carried out according to certain directions of activity of the enterprise.

The fourth stage. Identification of business processes' objectives selected in Stage 3. The strategic goals are achieved in the process of functioning of the enterprise through the implementation of business processes. For each business process, goals and objectives must be defined, the achievement and realization of which are determined by obtaining results.

When formulating the tasks of business processes, in addition to the strategic goals of the enterprise, the following aspects must be considered:

- business process opportunities, due to the technology of input conversion;

- available business process resources;

- requirements of internal and external consumers for the quality of output;

- balance of tasks of business process.

Stage Five. Determining the criteria for estimation of the effectiveness of the enterprise's business processes. The effectiveness of the enterprise's business processes is evaluated on the basis of revealed criteria characterizing such aspects of the enterprise's activity as financial-economic, production (resource), organizational, inter-firm (external integration). The maximum approximation of the actual value of the indicator to the planned is thought to be a positive feature. The system of indicators within the proposed criteria should be periodically reviewed in order to provide accurately reflection of the enterprise's effectiveness.

The sixth stage. Formation of indicators of effectiveness of business processes in the framework of the suggested criteria. Performance indicators characterize the degree of accomplishment of the business process objectives and the intended results. Effectiveness indicators reflect how optimized the resources are and how much loss is made in 
achieveing the desired result. The number of indicators depends on the specifics of each business process, the goals and other factors.

In order to obtain reliable information on the functioning of business processes, it is necessary to determine the monitoring methods. Monitoring refers to the methodology and system of observation of the state of a particular business process, the ability to observe it in development, which gives the opportunity to evaluate and identify the results of various factors.

Properly organized business process monitoring allows you to:

- identify the weaknesses of business processes where the occurrence of problems and disruptions in work is the most likely to happen;

- identify business processes with potential opportunities to save time and reduce costs;

- check compliance with the scheduled time of business processes;

- check the compliance of the real level of costs in business processes to the planned;

- determine the required amount of resources to perform business processes.

\section{CONCLUSIONS}

The analysis of the theoretical foundations of the process approach revealed that business processes are the basis on which process-oriented enterprise management is based. The process approach requires management to take action to adapt to change and, as a consequence, improve business processes.

Business process reengineering is defined as one of the effective tools of enterprise management. The suggested procedure is a further development of applied aspects of reengineering, taking into account the industry specificity of enterprises. Therefore, in the future, it is necessary to involve mechanisms of diagnostics of business process efficiency, which will allow timely identification of «bottlenecks» in the activity of the enterprise and the reasons for their appearance, as well as stimulate employees' initiative to participate in the development and implementation of reengineering projects and to support the concept of constant changes in economic activity. These factors will improve the effectiveness of the enterprise and ensure its competitiveness. 
The enterprise management system should be aimed at improving effectiveness, that requires the creation of a system of activity analysis and decision-making, which not only isolates and eliminates the causes of existing discrepancies, but also determines their possible occurrence. In order to effectively manage business processes, it is necessary to evaluate their status, since any changes in the conditions or results of business processes can only be determined when there are appropriate criteria and methods for measuring them. In this regard, the primary task in this aspect is to formulate a system of indicators of business process effectiveness, taking into account the specific activity of the enterprise. Based on measuring and analyzing the effectiveness of existing business processes, measures are being developed to improve them with appropriate mechanisms and tools.

Thus, the analysis data will allow to quantify business processes by defined indicators, in order to find problems and make effective management decisions to improve the business processes.

\section{SUMMARY}

The main issues related to process-oriented management of enterprises have been revealed. The development of scientific research on traditional management concepts has been investigated. The most significant advantages of the process approach in comparison with the functional one have been conducted by the author. The comparison criteria have been identified and argued. Emphasis is placed on functional and process management, as modern principles of process management which are based on modeling business processes that describe how different management functions are performed. The main reasons for implementing the process approach at the enterprise have been identified. The main stages of implementation of the process approach have been distinguished, which indicate that the process approach includes not only the description of business as a network of interconnected business processes, but also continuous monitoring, management and improvement of business processes.

The expediency of using reengineering to improve business processes has been substantiated. The author's vision of the definition of «reengineering» has been given. The procedure of selection of business processes to be reengineered at the enterprise has been developed and the stages of formation of evaluation criteria as well as the indicators of business processes have been formed. 


\section{REFERENCES:}

1. Ansoff I. (1989) Strategicheskoye upravleniye [Strategic Management]. Moscow: Economic. (in Russian)

2. Redchenko K. I. (2003) Stratehichnyi analiz u biznesi [Strategic analysis of business]. Lviv: The New World - 2000. (in Ukrainian)

3. Gershun A. (2006) Tekhnologii sbalansirovannogo upravleniya [Technologies of the balanced management]. Moscow: Olimp-Biznes. (in Russian)

4. Tompson A., Stryklend A.Dzh. (2005) Strategycheskyj menedzhment: koncepcyy y sytuacyy dlja analyza [Strategic Management: Concepts and situations for analysis]. Moscow: Williams. (in Russian)

5. Albrekht N. A. (2007). Sistema korporativnykh standartov: praktika razrabotki i vnedreniya. Reglamentatsiya biznes-protsessov [The system of corporate standards: the practice of development and implementation. Regulation of business processes]. Management Accounting and Finance, no. 2, pp. 144-152.

6. Jeston J., Nelis J. (2006) Business Process Management: Practical Guidelines to Successful Implementations. Amsterdam: Elsever.

7. Meskon M., Albert M., Hedouri F. (2005) Osnovy menedzhmenta [Fundamentals of Management]. Moscow: Delo. (in Russian)

8. Fayolle A., Emerson G., Taylor F., Ford G. (2002) Menedzhment - eto iskusstvo [Management - is art]. Moscow: Unity. (in Russian)

9. Repin V. V., Yeliferov V. G. (2008) Protsessnyy podkhod $k$ upravleniyu. Modelirovaniye biznes-protsessov [Process approach to management. Business process modeling]. 6th ed. Moscow: Standards and quality. (in Russian)

10. Azriljan A. (ed.) (2010) Bol'shoj jenciklopedicheskij slovar' [The Great Encyclopedic Dictionary]. Moscow: Knizhnyj mir. (in Russian)

11. Rajzberg B. A., Lozovskij L. Sh., Starodubceva E. B. (1999) Sovremennyj jekonomicheskij slovar' [Modern Economic Dictionary]. Moscow: INFRA-M. (in Russian)

12. Andersen B. (2003) Biznes-protsessy. Instrumenty sovershenstvovaniya [Business processes. Improvement tools]. Moscow: Standards and Quality. (in Russian) 
13. Totskiy V.I., Lavrenenko B. I. (2005) Orghanizacijnyj rozvytok pidpryjemstva [Organizational development Enterprise]. Kiev: KNEU. (in Ukrainian)

14. Abdelkafi N., Täuscher K. (2016) Business models for sustainability from a system dynamics perspective. Organization and Environment, vol. 29, no. 1, pp. 74-96.

15. Antunes P., Mourão H. (2011) Resilient business process management: Framework and services. Expert Systems with Applications, vol. 38, no. 2, pp. 1241-1254.

16. Cherchata A. (2016) Formuvannja pokaznykiv rezuljtatyvnosti ta efektyvnosti biznes-procesiv na osnovi koncepciji Balanced Scorecard (BSC) [Formation of Indicators of Resultativity and Effectiveness of Business Processes on the Basis of the Balanced Scorecard (BSC) Concept]. Scientific Bulletin of Ivano-Frankivsk National Technical University of Oil and Gas, vol. 14, no. 2, pp. 137-143.

17. Cherchata A., Popovychenko I., Andrusiv U., Simkiv L., Kliukha O., Horai, O. (2020) A methodology for analysis and assessment of business processes of Ukrainian enterprises. Management Science Letters, vol. 3, no. 10, pp. 631-640.

18. Kratzer S., Lohmann P., Roeglinger M., Rupprecht L., zur Muehlen M. (2019) The role of the chief process officer in organizations. Business Process Management Journal, vol. 4, no. 25, pp. 688-706.

19. Trkman P., Mertens W., Viaene S., Gemmel P. (2015) From business process management to customer process management. Business Process Management Journal, vol. 2, no. 21, pp. 250-266.

20. Lederer M., Kurz M., Lazarov P. (2017) Making strategy work: A comprehensive analysis of methods for aligning strategy and business processes. International Journal of Business Performance Management, vol. 18, no. 3, pp. 274-292.

21. Becker J., Kugeler M., Rosemann M. (2010) Process management. Berlin, Germany: Springer.

22. Mizyuk B. M. (2006) Stratehichne upravlinnya [Strategic management]. Lviv: Magnolia plus. (in Ukrainian)

23. Davenport T. (1993) Process innovation: reengineering work through information technology. Boston: Harvard Business School Press.

24. Johansson H., McHugh P., Pendlebury J. (1993) Business process reengineering. Break-point strategies for market dominance / H. Johansson. N.Y.: John Wiley \& sons. 
25. Manganelii R. L., Klein M. M. (1994) The reengineering handbook: a step-by-step guide to business transformation. N.Y.: Amacom.

26. Vinogradova O. V. (2006) Reinzhyniryng torgivel'nyh pidpryjemstv: teorija ta metodologija [Reengineering of trading enterprises: theory and methodology] (Doctoral thesis), Donetsk.

27. ISO 9001-2008 Quality management systems. Fundamentals and vocabulary. Retrieved from: http://www.iso.org

28. ISO 9004-2008 Quality management systems. Guidelines for performance improvements. Retrieved from: http://www.iso.org

\section{Information about the author:} Cherchata A. O.

$\mathrm{PhD}$ in Economics, Associate Professor, Department of Management, Project Management and Logistics, SHEE «Pridneprovsk State Academy of Civil Engineering and Architecture» (Ukraine) ORCID: https://orcid.org/orcid.org/0000-0002-6753-2891 